Combs, G. F., Carlson, C. W., Miller, R. F., Peeler, H. T., Norris, L. C. \& Heuser, G. F. (1950). 7. biol. Chem. 182, 727.

Cooley, G., Ellis, B., Petrow, V., Beaven, G. H., Holiday, E. R. \& Johnson, E. A. (1951). F. Pharm. Pharmacol. 3, 271.

Cooperman, J. M., Drucker, R. \& Tabenkin, B. (1951). J. biol. Chem. I9I, I35.

Cuthbertson, W. F. J., Pegler, H. F. \& Lloyd, J. T. (I95I). Analyst, 76, 333.

De Heus, J. G. \& De Man, T. J. (195r). Voeding, 12, 36r.

Ellis, B., Petrow, V., Beaven, G. H., Holiday, E. R. \& Johnson, E. A. (1950). F. Pharm. Pharmacol. 2, 735.

Ford, J. E., Kon, S. K. \& Porter, J. W. G. (1951). Biochem. F. 50, ix.

Ford, J. E. \& Porter, J. W. G. (1952). Biochem. F. 51, v.

Gregory, M. E., Ford, J. E. \& Kon, S. K. (1952). Biochem. F. 5r, xxix.

Harris, L. J. (1949). Brit. F. Nutrit. 2, 362.

Harrison, E., Lees, K. A. \& Wood, F. (1951). Analyst, 76, 696.

Hutner, S. H., Provasoli, L., Stokstad, E. L. R., Hoffmann, C. E., Belt, M., Franklin, A. L. \& Jukes, T. H. (1949). Proc. Soc. exp. Biol., N.Y., 70, 118.

Kaczka, E., Wolf, D. E., Kuehl, F. A. Jr \& Folkers, K. (1950). Science, r12, 354.

Lewis, U. J., Tappan, D. U. \& Elvehjem, C. A. (1950). Abstr. Pap. Amer. chem. Soc. 118th Mtg, p. $72 \mathrm{C}$.

Meyer, C. E., Eppstein, S. H., Bethell, F. H. \& Hall, B. E. (1950). Fed. Proc. 9, 205.

Pfiffner, J. J., Calkins, D. J., Peterson, R. C., Bird, O. D., McGlohon, V. \& Stipek, R. W. (I95I) Abstr. Pap. Amer. Chem. Soc. 120th Mtg, p. 22 C.

Picken, J. C. \& Bauriedel, W. R. (1950). Proc. Soc. exp. Biol., N.Y., 75, 51 1.

Pierce, J. V., Page, A. C. Jr., Stockstad, E. L. R. \& Jukes, T. H. (I949). F. Amer. chem. Soc. 7r, 2952.

Robbins, W. J., Hervey, A. \& Stebbins, M. E. (1950). Bull. Torrey bot. Cl. 77, 423.

Robbins, W. J., Hervey, A. \& Stebbins, M. E. (1951). Bull. Torrey bot. Cl. 78, 363.

Ross, G. I. M. (1950). Nature, Lond., 166, 270.

Shaw, G. E. (1950). Biochem. Y. 47, xxxv.

Skeggs, H. R., Nepple, H. M., Valentik, K. A., Huff, J. W. \& Wright, L. D. (1950). F. biol. Chem. 184,211 .

Smith, E. L. (1948). Nature, Lond., 162, 144.

Smith, E. L. (1950-1). Nutr. Abstr. Rev. 20, 795.

Smith, E. L., Fantes, K. H., Ball, S., Ireland, D. M., Waller, J. G., Emery, W. B., Anslow, W. K. \& Walker, A. D. (195I). Biochem. F. 48, I.

Snell, E. E. \& Wright, L. D. (1950). Ann. Rev. Biochem. 19, 277.

Soars, M. H. \& Hendlin, D. (195I). F. Bact. 62, 15.

Tarr, H. L. A. (195I). Canad. $\mathcal{~}$. Tech. 29, 391.

Ternberg, J. L. \& Eakin, R. E. (1949). F. Amer. chem. Soc. 7I, 3858.

Veer, W. L. C., Edelhausen, J. H., Wijmenga, H. G. \& Lens, J. (1950). Biochim. biophys. Acta, 6,225 .

Wijmenga, H. G. (195I). Onderzoekingen over vitamine $B_{12}$ en verwante factoren. Doctorate Thesis, University of Utrecht.

Wijmenga, H. G., Veer, W. L. C. \& Lens, J. (1950). Biochim. biophys. Acta, 6, 229.

\title{
The Nutritional Significance of the Animal Protein Factor and Antibiotics
}

\section{By W. F. J. Cuthbertson, Glaxo Laboratories Ltd., Greenford, Middlesex}

Diets composed wholly of vegetable materials have for some time been known to be inadequate for the growth of chicks (Hammond \& Titus, r944a, $b$; Rubin \& Bird, 1946) or rats (Zucker \& Zucker, 1948), even when supplemented with all the previously recognized vitamins. The factor (or group of factors) essential for the growth of animals maintained on these diets came to be called the 'animal protein factor' (APF) and was soon shown, though not a protein, to be present in materials of animal origin, e.g. milk, meat, liver, fish meal and cow manure (Rubin, Groschke \& Bird, 1947; Bird, Rubin \& Groschke, 1948).

The growth of chicks and pigs on wholly vegetable diets was greatly improved by administration of vitamin $\mathrm{B}_{12}$ (Ott, Rickes \& Wood, 1948; Hogan \& Anderson, 1949), 
and in experiments with vitamin $B_{12}$ it was found to be equivalent to a liver fraction or to 'fish solubles'. Several other workers (Sunde, Cravens, Elvejhem \& Halpin, I95०; Hill \& Branion, r950; Swenson, 195I) reported that vitamin $B_{12}$, even when given with all other known growth factors, could not fully replace the effects of foods of animal origin in the diets of chickens and turkeys. These discordant findings can now be explained by considering the previous history of the experimental animals, for Coates, Harrison \& Kon (1950) demonstrated that vitamin $B_{12}$ could fully replace animal protein if chicks from normal hens or hens recently placed on a deficient diet were used, whereas for chicks derived from hens maintained for some months on the deficient diet vitamin $B_{12}$ alone was not fully effective.

Stokstad, Jukes, Pierce, Page \& Franklin (1949) showed that supplementation of an all-vegetable ration with certain fermentation products, used as a source of vitamin $B_{12}$, led to much better growth than could be obtained even with superoptimal amounts of vitamin $B_{12}$; indeed, the growth was better than with vitamin $B_{12}$ and a source of animal protein factor, such as fish solubles, given together. Further work showed that the growth-promoting activity of this fermentation product was associated with its aureomycin content, and that supplementation with both aureomycin and vitamin $\mathrm{B}_{12}$ was as effective as the whole fermentation product in promoting growth of chicks on rations deficient in animal protein (Stokstad \& Jukes, 1950). Other antibiotics also, in particular penicillin, terramycin and bacitracin, were soon shown to be effective in promoting the growth of chicks, rats, turkeys and pigs maintained on wholly vegetable diets supplemented with vitamin $B_{12}$ (Cuthbertson, 1952).

That the antibiotics exert their effects through an action on the gut flora seems probable for the following reasons:

(I) The active concentrations in the food are so low that antibacterial concentrations in the tissues are unlikely to result.

(2) Injected antibiotics are not as effective as those orally administered.

(3) Antibiotic activity appears to be the only property shared by this chemically diverse group of substances.

Aureomycin, terramycin, penicillin and streptomycin were found to increase the growth of chicks even on excellent rations containing ample animal protein (Coates, Harrison, Kon, Mann \& Rose, I951; Biely, March, Stevens \& Casorso, 1951). Aureomycin has also been shown to improve the growth and survival of premature infants (Robinson, 1952).

Foods of animal origin (APF) improve growth on vegetable rations because they contain vitamin $B_{12}$ and other undescribed growth factors. Some antibiotics, when given with vitamin $B_{12}$, also increase growth and in most instances supplements of this type produce even better growth than do unsupplemented rations containing APF in food of animal origin. It is not known whether antibiotic supplements can fully replace exogeneous APF over the whole life cycle.

The use of the term APF is perhaps best avoided when referring to supplements that depend, for some or all of their effects, on their antibiotic content. The description APF should thus be reserved for those supplements, free from antibiotics, such as foods of animal origin that promote growth on wholly vegetable rations. This should 
prevent any confusion that could arise between the two types of supplement, which do differ in their modes of action and certain of their effects. The investigation of the unidentified factors in foods of animal origin is complicated because of the possible effects of the gut flora on their synthesis (or destruction) and the probability that the factors can be transferred through the egg, or the placenta and milk, to the next generation. The use of germ-free animals would appear to offer great advantages in investigation of these factors, but even with their use the problem of characterizing the factors would be difficult.

In our laboratories penicillin was found to have no effect on the growth of chicks offered rations containing animal protein, whereas penicillin always increased the growth rate of chicks in the laboratories at the National Institute for Research in Dairying, at Shinfield. To investigate this discrepancy a joint experiment was carried out. The same batch of food and chicks from the same hatch were shared between the two laboratories. Similar results were again obtained; in that at Shinfield the birds receiving penicillin grew better than the others, whereas at Greenford the birds grew equally well, with or without the addition of penicillin to their food, as can be seen in Table I. The observation that the growth of the birds at Greenford on either

\section{Table 1. The effect of penicillin on the growth of chicks on National Baby Chick Mash*}

(Mean weights (in g) at 3 weeks of age of groups of twenty Rhode Island Red $\times$ Light Sussex cockerels)

$\begin{array}{lcc}\text { Laboratory } & 0 & 40 \\ \begin{array}{c}\text { National Institute for Research in } \\ \text { Dairying, Shinfield }\end{array} & 167 & 192 \\ \text { Glaxo Laboratories, Greenford } & 188 & 191 \\ \text { * Coates, Dickinson, Harrison, Kon, Cummins \& } & 0 \text { Cuthbertson (195I). }\end{array}$

regime was as good as or better than the growth of the penicillin-treated birds at Shinfield led to the hypothesis that the latter suffered from some condition depressing growth and eliminated by dietary penicillin. Further work (Coates, Dickinson, Harrison, Kon, Porter, Cummins \& Cuthbertson, 1952) has clearly demonstrated the presence in the Shinfield laboratories of a highly infectious condition, overcome by oral penicillin and best described as 'the inability to grow adequately in the absence of dietary antibiotics'. Direct contact between birds is not necessary for spreading of this infection, which is not transmitted through the egg.

The condition is not associated with any increased mortality (the death rate in both laboratories is about the same and less than $3 \%$ ) or with any known poultry disease. The absence of this infection from Glaxo Laboratories may be explained by the previous complete exclusion of all adult poultry from those laboratories, for till recently birds were seldom kept, whereas at Shinfield birds have been continuously maintained for the past to years. The possibility that an infection of this type may be widespread is indicated by the many reports that antibiotics improve the growth of birds on normal diets: further support is given by Davis \& Briggs (1950), who noted 
that in their new poultry houses growth of untreated birds appeared at first to be about the same as that of birds given antibiotics in their old poultry houses.

Although an infective condition of this type may explain many of the growth responses obtained with dietary antibiotics, it cannot explain all; thus, in our laboratory dietary penicillin has little effect on rats given milk-yeast-cereal diets, but invariably improves the growth of animals on vitamin $B_{12}$-deficient rations (Cuthbertson

Table 2. Effect of dietary antibiotics and vitamin $\mathrm{B}_{12}$ on growth of chicks maintained on vegetable rations in the absence of an infective condition depressing growth

(Mean weights (in $\mathrm{g}$ ), with their standard errors, at 5 weeks of age of groups of twelve Light Sussex $\times$ Rhode Island Red pullets)

$\begin{array}{cccc}\text { Diet } & \begin{array}{c}\text { Procaine penicillin } \\ \text { (mg/kg diet) }\end{array} \\ \text { All-vegetable } & \begin{array}{c}\text { Vitamin } B_{12} \\ (\mu \mathrm{g} / \mathrm{kg} \text { diet) }\end{array} & 0 & 40 \\ \text { National Baby Chick Mash } & 0 & 369 \pm 13 & 401 \pm 14 \\ 4200 & 0 & 38 \pm \pm 16 & 381 \pm 12\end{array}$

\& Thornton, unpublished). Further, in our laboratory dietary penicillin increases the growth of chicks offered wholly vegetable rations even when the infective condition can be proved to be absent (Table 2 above; Cummins, Cuthbertson \& Flynn, unpublished).

The different effects of dietary antibiotics on the growth of animals appear to depend to some extent on what has been called the 'disease level' (a better term would probably be 'microbiological status') of the animals studied.

(I) Antibiotics may often be effective by elimination of frank intestinal infections; thus, in much published work on pigs it is clear that the animals studied were suffering from scours, and in many instances the reported reduction of mortality and increased growth of chicks and turkeys may also have been due to elimination of disease. Speer, Vohs, Catron, Maddock \& Culbertson (1950), for example, found antibiotics ineffective when given to pigs kept under first-class hygienic conditions.

(2) The elimination of growth-depressant infective conditions that depress growth but do not cause disease or increased mortality may also frequently be responsible for the beneficial effects of antibiotics (Coates, Dickinson, Harrison, Kon, Cummins \& Cuthbertson, 195 ; Coates et al. I952).

(3) In the absence of conditions (I) and (2) antibiotics appear to have no effect on the growth of rats and chicks receiving adequate diets, though improvements are still obtained with animals fed on all-vegetable rations (Cummins, Cuthbertson, Flynn \& Thornton, unpublished).

(4) The effect of antibiotics in the complete absence of intestinal micro-organisms is not yet known and its study should be of great interest.

The amounts of antibiotic required are very small-2-15 g/ton of food eatenand only small changes have been noted in the gut flora on applying the classical methods of bacteriology. 
The presence of antibiotics could modify growth in several different ways, thus:

(i) by elimination of known pathogens;

(ii) by elimination of micro-organisms depressing growth,

(a) that produce toxins,

(b) that compete for essential nutrients;

(iii) by modification of bacterial metabolism or production of antibiotic-resistant strains with modified metabolism,

(a) with reduced requirements for essential nutrients,

(b) without ability to adsorb essential nutrients,

(c) with increased powers of synthesis or secretion of essential nutrients;

(iv) by elimination of antibiotic-sensitive organisms, leading to increased growth of other types, which could either,

(a) not compete for essential nutrients,

(b) synthesize growth factors.

Apart from their effects on frank disease and the infection that depresses growth, antibiotics modify growth by improving the efficiency of utilization of certain vitamins in both the chick and the rat (Coates, Dickinson, Harrison \& Kon, 1951; Lih \& Baumann, 195I ; Biely \& March, 195I). This vitamin-sparing action, at least for vitamin $B_{12}$, is demonstrable even in the absence of any growth-depressant infection (Cummins, Cuthbertson \& Flynn, unpublished).

\section{REFERENCES}

Biely, J. \& March, B. (195I). Science, II4, $33^{\circ}$.

Biely, J., March, B., Stevens, J. \& Casorso, R. (195I). Poult. Sci. 30, 143.

Bird, H. R., Rubin, M. \& Groschke, A. C. (1948). F. biol. Chem. I74, 61 I.

Coates, M. E., Dickinson, C. D., Harrison, G. F. \& Kon, S. K. (I95I). Biochem. Y. 49, Ixviii.

Coates, M. E., Dickinson, C. D., Harrison, G. F., Kon, S. K., Cummins, S. H. \& Cuthbertson, W. F. J. (1951). Nature, Lond., 168, 332.

Coates, M. E., Dickinson, C. D., Harrison, G. F., Kon, S. K., Porter, J. W. G., Cummins. S. H. \& Cuthbertson, W. F. J. (1952). F. Sci. Food Agric. 3, 43.

Coates, M. E., Harrison, G. F. \& Kon, S. K., (1950). Biochem. 7. 46, vii.

Coates, M. E., Harrison, G. F., Kon, S. K., Mann, M. E. \& Rose, C. D. (195I). Biochem. F. 48, xii.

Cuthbertson, W. F. J. (1952). F. Sci. Food Agric. 3, 49.

Davis, R. L. \& Briggs, G. M. (1950). Poult. Sci. 30, 767.

Hammond, J. C. \& Titus, H. W. (r944a). Poult. Sci. 23, 49.

Hammond, J. G. \& Titus, H. W. (1944b). Poult. Sci. 23, 47 x.

Hill, D. C. \& Branion, H. D. (1950). Poult. Sci. 29, 405.

Hogan, A. G. \& Anderson, G. C. (1949). Fed. Proc. 8, 385.

Lih, H. \& Baumann, C. A. (195I). F. Nutrit. 45, 143.

Ott, W. H., Rickes, E. L. \& Wood, T. R. (1948). F. biol. Chem. 174, 1047.

Robinson, P. (1952). Lancet, 262, 52.

Rubin, M. \& Bird, H. R. (1946). F. biol. Chem. 163, $3^{87}$.

Rubin, M., Groschke, A. C. \& Bird, H. R. (1947). Proc. Soc. exp. Biol., N.Y., 66, 36.

Speer, V. C., Vohs, R. L., Catron, D. V., Maddock, H. M. \& Culbertson, C. C. (1950). Arch. Biochem. 29, 452 .

Stokstad, E. L. R. \& Jukes, T. H. (1950). Proc. Soc. exp. Biol., N.Y., 73, 523.

Stokstad, E. L. R., Jukes, 'T. H., Pierce, J., Page, A. C. Jr. \& Franklin, A. L. (1949). F. biol. Chem. r8o, 647 .

Sunde, M. L., Cravens, W. W., Elvehjem, C. A. \& Halpin, J. G. (1950). Poult. Sci. 29, 204.

Swenson, M. J. (1951). Poult. Sci. 30, 55.

Zucker, L. M. \& Zucker, T. F. (1948). Proc. Soc. exp. Biol., N.Y., 68, 432. 